\title{
Impact of Seed Treatments with Fungal Biocontrol Agents on Enzymatic Activities and Phenolic Content of Soybean under Greenhouse and Field Conditions
}

\author{
Anum Intisar ${ }^{1^{*}}$, Zafar Iqbal ${ }^{1}$ and Shahbaz Talib Sahi ${ }^{2}$ \\ ${ }^{1}$ Department of Plant Pathology, College of Agriculture, University of Sargodha, Pakistan \\ ${ }^{2}$ Department of Plant Pathology, University of Agriculture, Faisalabad, Pakistan \\ *For correspondence: anum.intisar2009uaf@gmail.com \\ Received 26 March 2021; Accepted 27 May 2021; Published 10 July 2021
}

\begin{abstract}
Fungi in the genus Trichoderma are widely used as biological control agents because they can suppress plant pathogens and activate plant defense systems. In the present study, efficacy of microbial antagonists viz., T. harzianum and T. viride or their combination was evaluated against the pathogenic fungus Macrophomina phaseolina and their effect on enzymatic activities and phenol content of soybean [Glycine max (L.) Merr.] plants. Soybean seeds were inoculated with T. harzianum and T. viride separately or in combination, and sown in pots under green house and under field conditions. Host enzymatic activities and phenol levels were measured at 14, 28 and 42 days after sowing (DAS) in both field and greenhouse experiments. Seed treatments with $T$. harzianum, $T$. viride or their combination increased peroxidase, polyphenol oxidase and $\beta$-1, 3-glucanase activities, and also the total phenol content in soybean leaves as compared to a non-treated control treatment. Concentration of peroxidase and $\beta$-1, 3-glucanasepeaked at 14 DAS and decreased thereafter in all the treatments under greenhouse and field conditions. All the treatments showed the highest levels of total phenols and polyphenol-oxidase at 28 DAS under both greenhouse and field conditions. At 14 DAS in both trials, the combination of $T$. viride $+T$. harzianum resulted in the highest level of peroxidase and $\beta$-1, 3-glucanase activities. This combination also resulted in the highest levels of total phenols and polyphenol oxidase content at 28 DAS. Our findings demonstrated that application of Trichoderma species as seed treatment has potential to trigger key mechanisms of systemically acquired resistance in soybean, and thereby enhanced efficacy of disease management tactics. (C) 2021 Friends Science Publishers
\end{abstract}

Keywords: Macrophomina phaseolina; Peroxidase; Phenolics; Seed inoculation; Soybean; Trichoderma

\section{Introduction}

Soybean is an important leguminous crop and a major source of vegetable oil and proteins worldwide. The crop is prone to many economically important fungal diseases of which charcoal rot caused by Macrophomina phaseolina is the major constraint causing significant losses every year (Marquez et al. 2021). This pathogen also causes diseases in other legumes such as chickpea, mungbean and mashbean (Banaras et al. 2021; Javed et al. 2021). Different management methods such as physical, chemical (fungicides), regulatory, cultural and biological have been used to control Macrophomina phaseolina (Khan and Javaid 2020a; Khan et al. 2021; Um-e-Aiman et al. 2021). However, these methods are helpful only when used well in advance as precautionary measures (Ganeshamoorthi et al. 2010; Marquez et al. 2021). In addition, conventional chemical fungicides for $M$. phaseolina infections may be less helpful due to soil-borne nature of the pathogen, and may interrupt the balance of beneficial microbes in the soils (Anis et al. 2010). Furthermore, the indiscriminate use of chemical pesticides and fungicides may develop resistance to pathogenic strains and can cause harmful environmental risks and health hazards (Afouda et al. 2012). Efforts to manage the disease in soybean through crop rotation has also been suggested (Mengistu et al. 2007), but it may be inadequate for control of soil-borne fungal diseases with long-surviving propagules such as charcoal rot. Therefore, alternative methods of disease control are need of the time.

During the past few decades, different biocontrol agents have been identified, characterized and commercialized (Javaid et al. 2021; Sharf et al. 2021). Biocontrol organisms have gained more attention as component of integrated disease management programs (Shahid and Khan 2019; Ali et al. 2020). Biological control is an effective way to enhance resistance in plants against pathogens, and this technique may play a significant role in sustainability of agricultural systems. Biocontrol organisms

To cite this paper: Intisar A, Z Iqbal, ST Sahi (2021). Impact of seed treatments with fungal biocontrol agents on enzymatic activities and phenolic content of soybean under greenhouse and field conditions. Intl J Agric Biol 26:294-302 
are helpful against seed- and soil-borne fungal diseases of several crops (Akhtar and Javaid 2018; Javaid et al. 2018; Yasmin et al. 2020). The fungus Trichoderma harzianum has been documented to suppress many soil-borne fungal pathogens including $M$. phaseolina (Mukhopadhyay and Kumar 2020; Khan and Javaid 2020b). Aly et al. (2007) enlisted different antagonists of Trichoderma spp. against $M$. phaseolina. Sreedevi et al. (2011) depicted that T. viride and $T$. harzianum isolates had antifungal activity against $M$. phaseolina. Trichoderma spp. act as biocontrol organisms and also stimulate the plant resistance and growth resulting in overall improvement in yield (Javaid et al. 2017; Shoaib et al. 2018). The biocontrol activity related to antibiotics and mycoparasitism also improves defense response or systemic resistance in plants (Naher et al. 2014). The germination percentage of melon was $96.7 \%$ when seeds were treated with commercial $T$. harzianum $+M$. phaseolina as compared to $M$. phaseolina alone (46.7\%) and showed excellent results against charcoal stem rot of water melon (Etebarian 2006). The antagonistic characteristics of the biocontrol species depend on multiple mechanisms that are involved in activation of specific properties (Khan and Javaid 2020b).

The most important mechanism of Trichoderma spp. is the induction of plant defense response to specific pathogens (Harman 2006; Inayati et al. 2020). Other than chemical and physical obstructions, plants have immune systems. The system is able to identify motifs that contain common structural features of all microbes but not present in their host plants. The defense response of plants is rapid, transitory and generalized. During biotic stress, host plant shows various cellular and physiological changes such as ion influx across the plasma membranes; activation of nitric oxide, defense-related genes; high production of ROS (reactive oxygen species), different phytohormones; biosynthesis of specific stress related proteins and production of antimicrobial chemicals such as phenolics (Wu et al. 2014; Nishad et al. 2020). Different biocontrol organisms may cause distinct molecular and cellular transformations in plants that enhance the resistance to biotic and abiotic stress (Brotman et al. 2013; Kumar 2013). The activity of defense-related enzymes such as phenylalanine ammonia lyase, polyphenol oxidase and peroxidase was documented to be progressively enhanced in plants of green gram (Vigna radiata) when inoculated with T. viride alone or in combination with Pseudomonas fluorescens against M. phaseolina (Thilagavathi et al. 2007). Tomato plants treated with $T$. arundinaceum showed early expression of defense-related genes against Rhizoctonia solani and Botrytis cinerea (Malmierca et al. 2012). Although there are reports on role of Trichoderma spp. as a biological control agent and induced defenserelated enzymatic changes in plants, however, there is little information available on combined effect of T. harzianum and $T$. viride to induce defense-related enzymes in soybean plants. Therefore, the main objective of the present investigation was to determine a suitable combination of
Trichoderma spp. in improving the enzymatic and phenolic contents of soybean under greenhouse and field conditions.

\section{Materials and Methods}

\section{Collection of fungal isolates}

Soybean plants infected with $M$. phaseolina were collected from soybean growing areas of Punjab, Pakistan. These infected samples were kept in polythene bags and brought to plant pathology laboratory for isolation and further processing. Potato dextrose agar (PDA) medium was used to culture M. phaseolina. For this purpose, $200 \mathrm{~g}$ peeled and sliced potatoes, $20 \mathrm{~g}$ agar and $20 \mathrm{~g}$ dextrose were used. The potatoes were sliced, boiled in $400 \mathrm{~mL}$ distilled water and their extract was used after filtration with muslin cloth. Likewise, agar was boiled in distilled water $(400 \mathrm{~mL})$; after boiling, $20 \mathrm{~g}$ of melted agar and $20 \mathrm{~g}$ of dextrose were mixed with potato extract. After preparation, the medium was autoclaved at $121^{\circ} \mathrm{C}$ for $30 \mathrm{~min}$. Symptomatic portions of stems were chopped into 5- to 7-mm long pieces. The chopped pieces were disinfested with mercuric chloride $(0.1 \%)$, washed with sterilized distilled water and then placed on PDA plates with the help of sterilized forceps. These PDA plates were incubated at $27 \pm 1^{\circ} \mathrm{C}$ for 4 days to get suitable growth of $M$. phaseolina. Characteristics of $M$. phaseolina were identified on the basis of formation of sclerotia and morphology of colony by following guidelines of Mahdizadeh et al. (2011). To maintain fungal culture in a viable condition, the PDA plates were placed in a refrigerator at $4^{\circ} \mathrm{C}$ until used.

For mass culturing of $M$. phaseolina, rice seeds were washed with distilled water, placed in narrow glass flasks of $250 \mathrm{~mL}$, and soaked with enough water to cover the seeds. The flasks were plugged with cotton and wrapped with aluminum foil. After $12 \mathrm{~h}$ seeds were autoclaved at $121^{\circ} \mathrm{C}$ for $30 \mathrm{~min}$. After cooling, $5 \mathrm{~mm}$ mycelial discs were taken from 7 days old culture of $M$. phaseolina, which had been prepared in PDA medium. These discs of $M$. phaseolina were placed in flasks containing rice seeds and incubated at $27 \pm 1^{\circ} \mathrm{C}$ for 15 days in dark. From $3^{\text {rd }}$ day on, flasks were stirred daily to avoid aggregate formation. After 15 days, the seeds were completely colonized showing black color and became ready for use. After incubation, the inoculum was kept at $4^{\circ} \mathrm{C}$ till further utilization in the experiments.

\section{Application of fungal antagonists}

Greenhouse experiment: Plastic pots $\left(17 \times 20 \times 20 \mathrm{~cm}^{3}\right)$ were filled with a mixture of clay, sand and peat (1:1:1). Soil was autoclaved at $121^{\circ} \mathrm{C}$ for $30 \mathrm{~min}$ for 2 successive days prior to use. For fungal bio-control agents, treatments were: $T$. harzianum alone, $T$. viridealone and $T$. harzianum $+T$. viride in combination at three levels of concentration of conidia $\left(2 \times 10^{4}, 2 \times 10^{6}\right.$ and $2 \times 10^{7}$ spores $\left.\mathrm{mL}^{-1}\right)$ (Karthikeyan et al. 2015). Equal concentration of each species was used 
in the combined treatment. The spore concentration was determined using hemocytometer.

Field experiment: Fungal bio-control agents or their combination i.e., T. harzianum, T. viride and T. harzianum + $T$. viride were used at the same concentrations as for greenhouse. Seeds of soybean variety NARC-3 $\left(80 \mathrm{~kg} \mathrm{ha}^{-1}\right)$ were treated with fungal bio-control agents using gum Arabicas sticky material. Seeds were coated with $1 \%$ gum Arabic (10 g for $1 \mathrm{~kg}$ of soybean seed) as an adhesive and suspended in the conidial suspension and kept at $25 \pm 2{ }^{\circ} \mathrm{C}$ in a rotary shaker for $6 \mathrm{~h}$ to ensure uniform coating. After coating, seeds were dried in shade, and then used for sowing. Both the experiments (greenhouse and field) were conducted in research area of University of Agriculture Faisalabad, Pakistan using RCBD with factorial arrangement and three replications. The net plot size for each treatment unit was $3 \times$ 3 meter. The inoculum of the pathogen $M$. phaseolina developed on rice grains was added along the length of the lines@6 $\mathrm{g} \mathrm{m}^{-1}$ along with sowing seeds. Crop was sown with the help of hands in rows in first week of February, 2017 and 2018. The distance between rows was $25 \mathrm{~cm}$, while between plants was $5 \mathrm{~cm}$. Fertilizers such as nitrogen, phosphorus and potassium were used @ 25,60, $50 \mathrm{~kg} \mathrm{ha}^{-1}$, respectively. When the crop needed water, it was irrigated and weeds were controlled manually during growing season.

\section{Observations}

Peroxidase activity, total phenol content (TPC), polyphenoloxidase (PPO) and $\beta$-1, 3-glucanase activity were determined in leaves of NARC-3 14, 28 and 42 days after sowing (DAS) in the field studies.

\section{Peroxidase (PO) activity}

The procedure for determining the activity of peroxidase was adopted from Fehrmann and Dimond (1967). Approximately $0.5 \mathrm{~g}$ fresh leaves of treated or non-treated (control) soybean leaves ground in a pre-chilled mortar with $0.1 M$ ice cold phosphate buffer $(20 \mathrm{~mL})$ at $\mathrm{pH}$ 7.1. Later on, it was kept for centrifugation (3000 rpm) for $15 \mathrm{~min}$. The supernatant $(25 \mathrm{~mL})$ was used for assay. Freshly prepared pyrogallol, reagent, enzyme extract and phosphate buffer were mixed in a cuvette tube and the blend was tuned to zero absorbance on a spectrophotometer. The activity of enzyme was measured as the alteration in absorbance per minute $(\Delta \mathrm{A} / \mathrm{min})$ at $430 \mathrm{~nm}$.

\section{Total phenol content (TPC)}

TPC was estimated by the Folin-Ciocalteu reagent method (Bray and Thorpe 1954). Folin-Ciocalteu reagent (1 mL) and $20 \%$ sodium carbonate $(2 \mathrm{~mL})$ were added together with ethanol extract $(1 \mathrm{~mL})$ in a test tube and then heated for $1 \mathrm{~min}$ in a boiling water bath. After cooling, distilled water was added and final volume was made up to $25 \mathrm{~mL}$. The absorbance of the blue color was determined with Spectronic-20 colorimeters at $725 \mathrm{~nm}$. Total phenol content was noted from the standard curve used for catechol.

\section{Polyphenol oxidase (PPO)}

Enzyme extract $(0.5 \mathrm{~mL})$ and $0.1 M$ phosphate buffer $(2.3$ $\mathrm{mL}$ ) were added to a cuvette, which was adjusted to zero absorbance on a spectrophotometer (Mahadevan and Sridhar 1982). A $0.2 \mathrm{~mL}$ aliquot of $0.1 M$ catechol was added and then reactants were rapidly mixed. The activity of enzyme was noted as variation in absorbance instantaneously after adding $0.1 M$ catechol $(0.2 \mathrm{~mL})$.

\section{$\beta$-1, 3-glucanase activity}

Approximately $1 \mathrm{~g}$ soybean leaves from each treatment were homogenized separately in a mortar containing $0.1 \mathrm{M}$. sodium phosphate buffer at $\mathrm{pH} 7.1$ at the rate of $2 \mathrm{~mL} \mathrm{~g}^{-1}$ fresh weight leaves for $1 \mathrm{~min}$. This preparation was then passed through cheese cloth and filterate was centrifuged at $3000 \mathrm{rpm}$ for $15 \mathrm{~min}$ at $6^{\circ} \mathrm{C}$. The clear supernatant was collected and considered to be a crude extract for enzymes assay. The supernatant was stored in the refrigerator at $20^{\circ} \mathrm{C}$ until determination of $\beta-1,3$-glucanase activity by following the procedure of El-Gamal et al. (2016).

\section{Statistical analysis}

Data were statistically analyzed using Statistix 8.1 software and means were compared by least significant difference test (LSD) at 5\% probability level.

\section{Results}

\section{$\beta$-1, 3-glucanase activity of soybean plants}

Fungal bio-control agents significantly increased $\beta-1,3-$ glucanase activity in soybean compared to the control under both greenhouse and field conditions. Among fungal biocontrol agents, $T$. harzianum $+T$. viride greatly increased $\beta$ 1, 3-glucanase activity (6.07 and $2.98 \mu \mathrm{g} \mathrm{g}^{-1}$ under greenhouse and field conditions, respectively) followed by $T$. harzianum, whereas plants treated with $T$. viride expressed the least $\beta$-1, 3-glucanase activity (3.75 and 1.37 $\mu \mathrm{g} \mathrm{g}^{-1}$ under greenhouse and field conditions, respectively). At 14 DAG, plants exhibited maximum $\beta$-1, 3-glucanase activity where $T$. harzianum $+T$. viride was applied $(9.88$ and $3.16 \mu \mathrm{g} \mathrm{g}^{-1}$ under greenhouse and field conditions, respectively) which had not changed at 28 DAG. At 42 DAG, plants expressed the lowest $\beta$-1, 3-glucanase activity where $T$. viride was applied (Fig. 1-4).

\section{Peroxidase activity of soybean plants}

Control plants had less peroxidase activity than bio-control 
Seed Treatment with Biocontrol Agents / Intl J Agric Biol, Vol 26, No 2, 2021

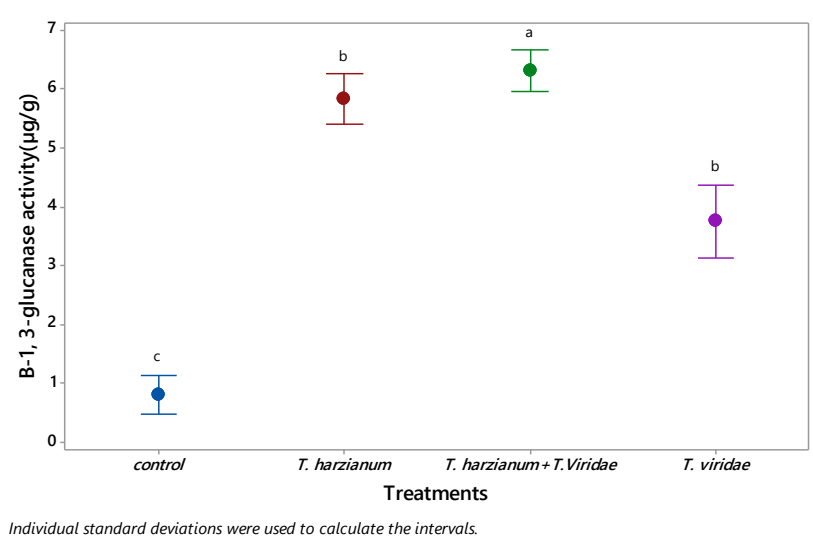

Fig. 1: Effect of fungal biocontrol agents on $\beta$-1, 3-glucanase activity of soybean under greenhouse conditions

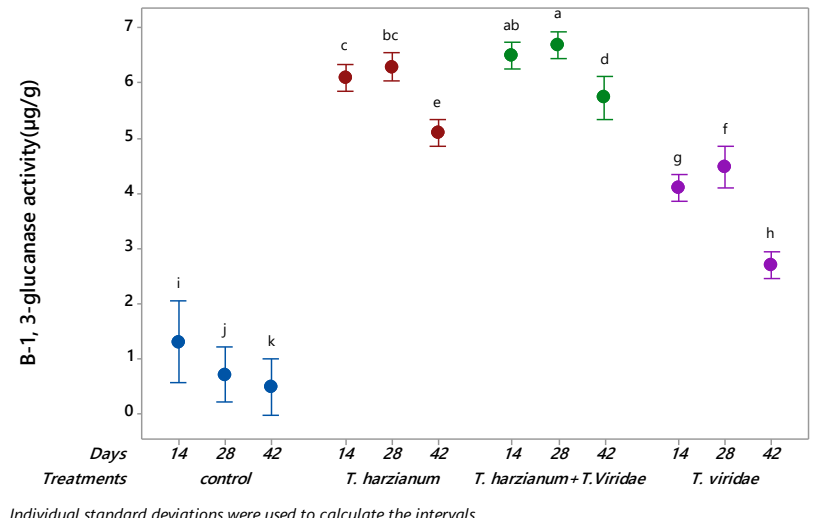

Fig. 2: Impact of interaction between fungal biocontrol agents and days on $\beta$-1,3-glucanase activity of soybean under greenhouse conditions

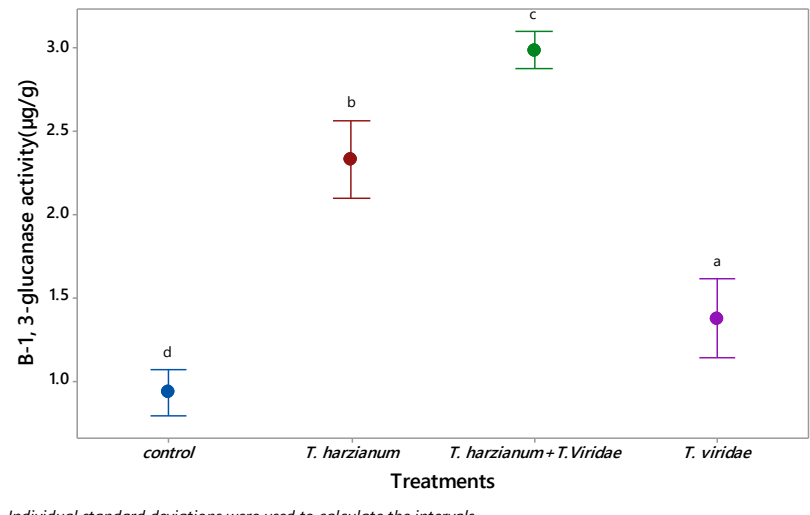

Fig. 3: Effect of fungal biocontrol agents on $\beta$-1, 3-glucanase activity of soybean under field conditions

agents (Fig. 5-8). Among fungal bio-control agents, $T$. harzianum $+T$. viride progressively improved peroxidase activity in soybean (3.05 and $1.98 \mu \mathrm{g} \mathrm{g}^{-1}$ under greenhouse and field conditions, respectively), while soil application of

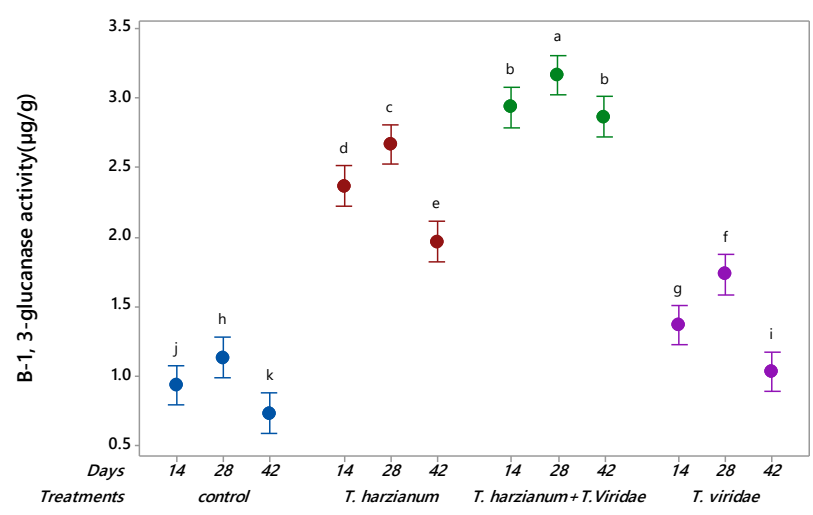

Individual standard deviations were used to calculate the intervals

Fig. 4: Impact of interaction between fungal biocontrol agents and days on $\beta-1,3$-glucanase activity of soybean under field conditions

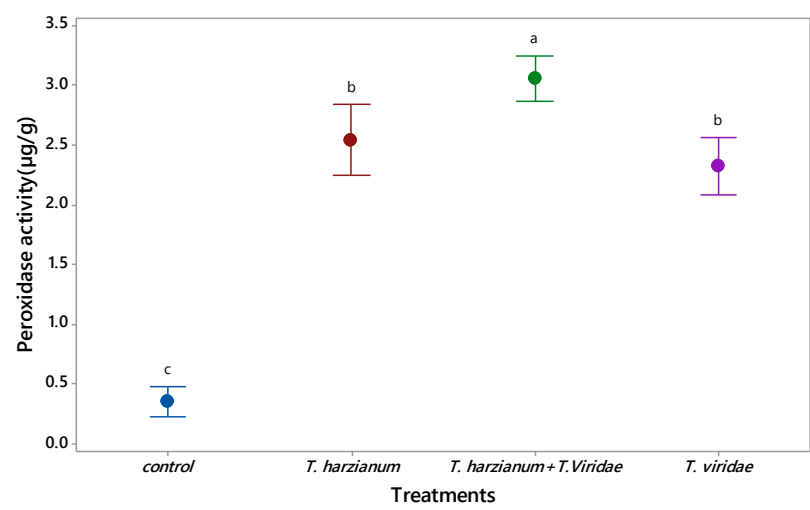

Individual standard deviations were used to calculate the intervals.

Fig. 5: Effect of fungal biocontrol agents on peroxidase activity of soybean under greenhouse conditions

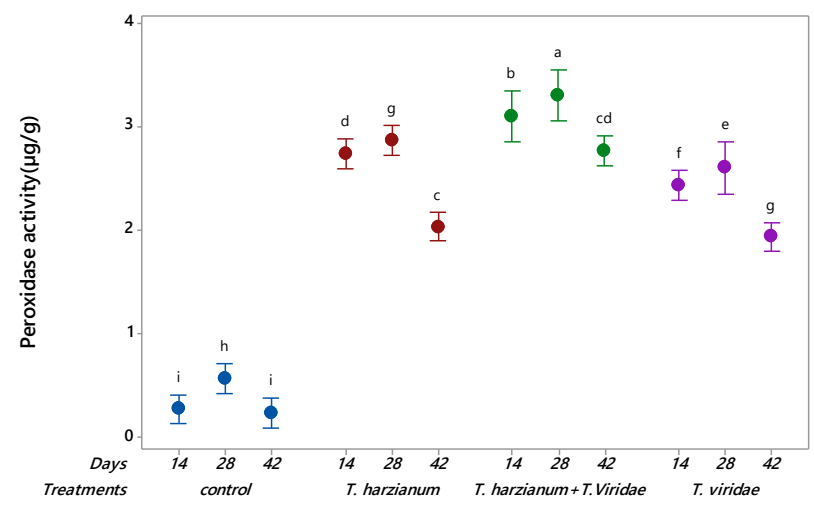

Individual standard deviations were used to calculate the intervals.

Fig. 6: Impact of interaction between fungal biocontrol agents and days on peroxidase activity of soybean under greenhouse conditions

T. viride expressed minimum peroxidase activity $(2.32 \mu \mathrm{g} \mathrm{g}$ ${ }^{1}$ ). At 28 DAG, plants with $T$. harzianum $+T$. viride showed maximum peroxidase activity (3.10 and $2.16 \mu \mathrm{g} \mathrm{g}^{-1}$ under 


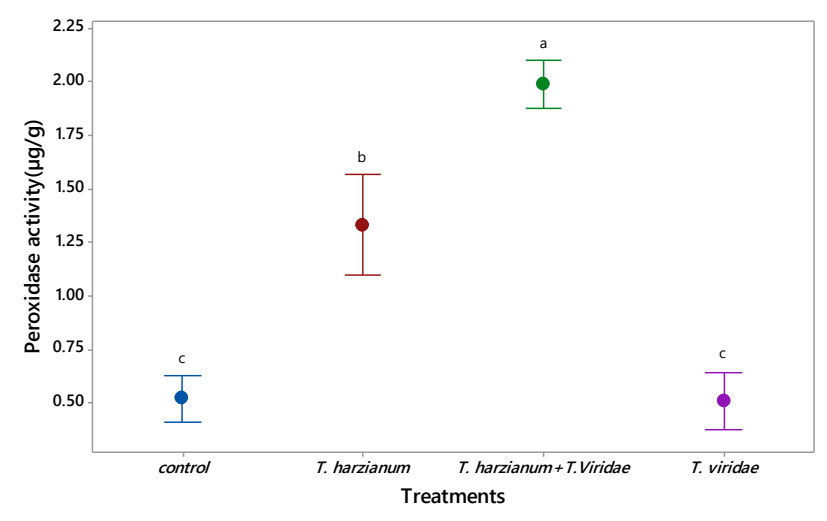

Individual standard deviations were used to calculate the intervals.

Fig. 7: Effect of fungal biocontrol agents on peroxidase activity of soybean under field conditions

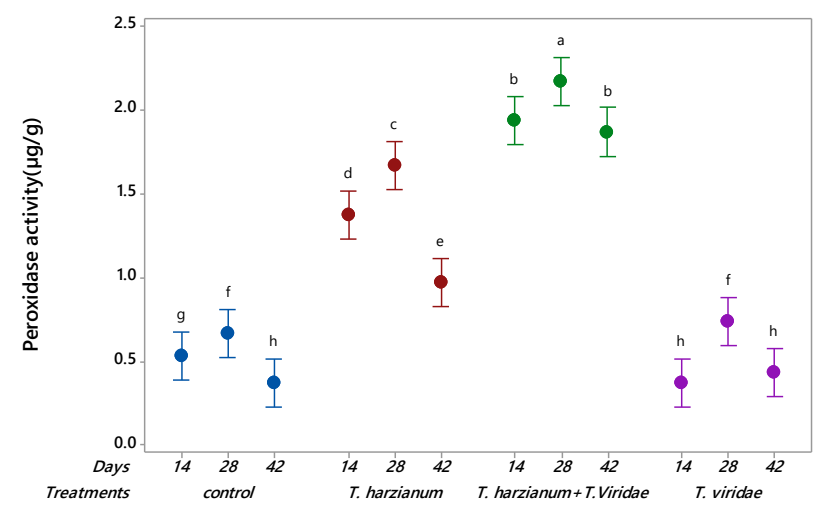

Individual standard deviations were used to calculate the intervals.

Fig. 8: Impact of interaction between fungal biocontrol agents and days on peroxidase activity of soybean under field conditions

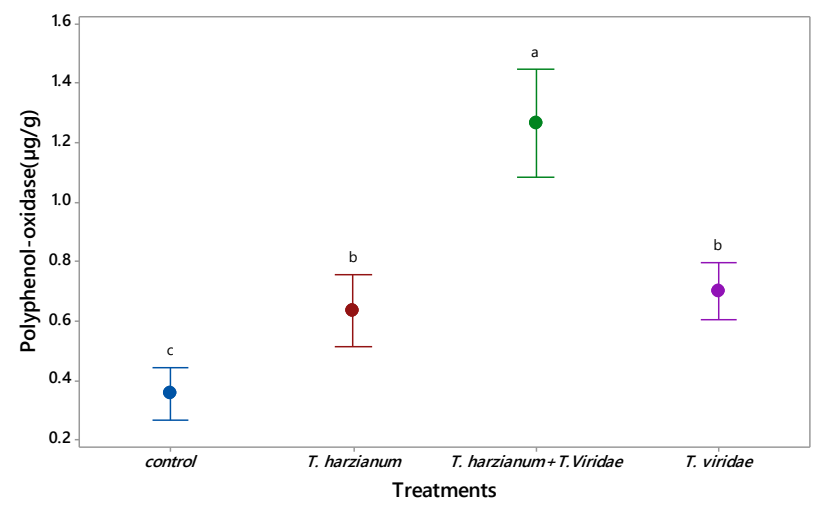

Individual standard deviations were used to calculate the intervals.

Fig. 9: Effect of fungal biocontrol agents on polyphenol-oxidase of soybean under greenhouse conditions

greenhouse and field conditions, respectively). Peroxidase activity decreased with passage of time to a minimum at 42 DAG in the $T$. viride treatment.

\section{Polyphenol oxidase (PPO) activity of soybean plants}

Concentration of PPO in leaves of soybean was consider ably higher when seeds were inoculated with fungal antagonists before sowing (Fig. 9-12) than in the noninoculated controls. Fungal bio-control agents also increased the PPO concentration in soybean leaves compared to control. Among fungal bio-control agents, $T$. harzianum $+T$. viride greatly enhanced PPO activity (1.26 and $\left.2.90 \mu \mathrm{g} \mathrm{g}^{-1}\right)$, whereas $T$. harzianum showed the least activity (0.63 and $\left.1.27 \mu \mathrm{g} \mathrm{g}^{-1}\right)$ under greenhouse and field conditions, respectively. At 42 DAG, PPO activity was the highest when $T$. harzianum $+T$. viride was applied $(1.50$ $\left.\mu \mathrm{g} \mathrm{g}^{-1}\right)$. Polyphenol-oxidase activity was the lowest $(0.50$ and $3.10 \mu \mathrm{g} \mathrm{g}^{-1}$ ) at $42 \mathrm{DAG}$ for the $T$. harzianum treatment under greenhouse and field conditions, respectively.

\section{Total phenol content (TPC)}

Fungal bio-control agents significantly enhanced total phenol content in soybean leaves compared to control (Fig. 13-16). The combination of $T$. harzianum $+T$. viride significantly improved total phenol content (3.41 and 4.20 $\mu \mathrm{g} \mathrm{g}^{-1}$ under greenhouse and field conditions, respectively), whereas $T$. viride exhibited the least total phenol. At 28 DAG, total phenol content was increased substantially when T. harzianum $+T$. viride was applied (3.83 and $4.66 \mu \mathrm{g} \mathrm{g}^{-1}$ under greenhouse and field conditions, respectively), which was equivalent to the values at $14 \mathrm{DAG}$. Total phenol content was the least at $42 \mathrm{DAG}$ in the $T$. viride treatment $\left(2.23 \mu \mathrm{g} \mathrm{g}^{-1}\right)$.

\section{Discussion}

In the present study, higher $\beta$-1, 3-glucanase, peroxidase, polyphenol oxidase activities and maximum total phenol content were observed in the soybean plants when seeds were sown after treatment with $T$. harzianum $+T$. viride, while the minimum values of these parameters were observed in the plants sown with untreated seed under both greenhouse and field conditions. These results indicate that combinations of $T$. harzianum $+T$. viride triggers stronger soybean defense signals than alone $T$. harzianum and $T$. viride. Increased activity of these host enzymes during plant-fungus interactions have been reported previously by several researchers (Khaledi and Taheri 2016; Yusnawan et al. 2019; Inayati et al. 2020). Peroxidase and $\beta$-1, 3glucanase play a significant role to initiate the plant defense response against various pathogens through production of highly toxic phenolic compounds and higher production of reactive oxygen species or establishment of structural barriers such as lignin accumulation (Yusnawan et al. 2019; Inayati et al. 2020). $\beta$-1,3-glucanase degrades the cell wall polysaccharides of fungal pathogens and kills the pathogens (Ueki et al. 2020). Khaledi and Taheri (2016) reported significant increase in peroxidase activity and 


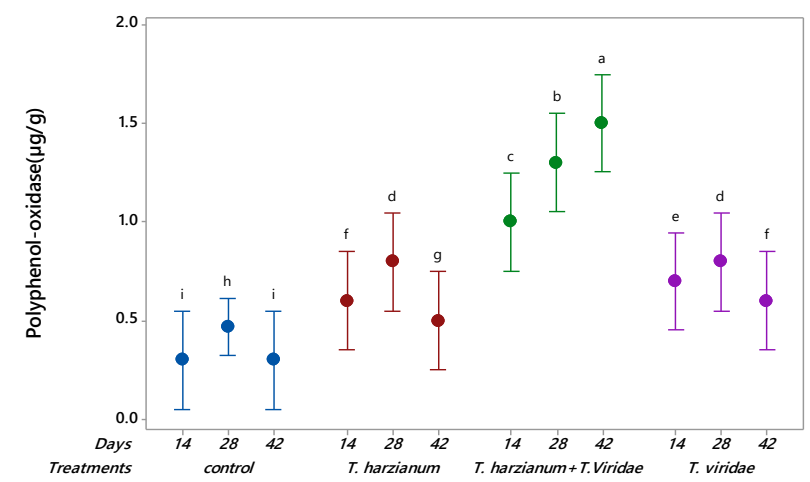

Individual standard deviations were used to calculate the intervals.

Fig. 10: Impact of interaction between fungal biocontrol agents and days on polyphenol-oxidase of soybean under greenhouse conditions

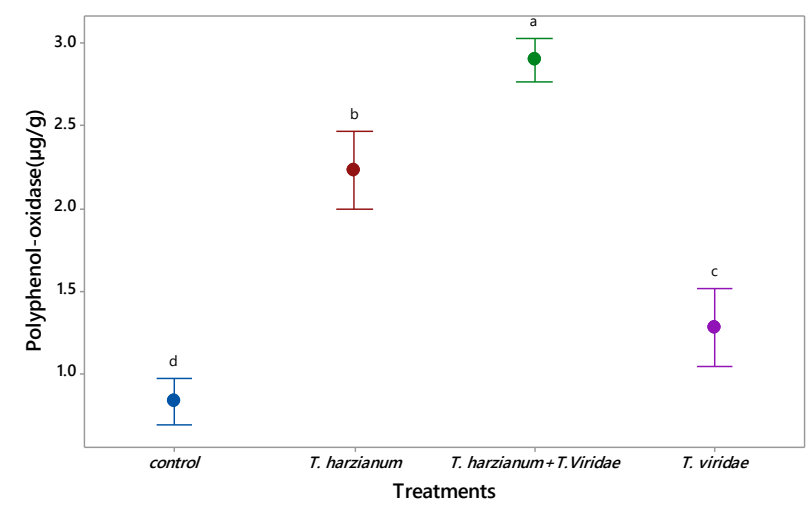

Individual standard deviations were used to calculate the intervals.

Fig. 11: Effect of fungal biocontrol agents on polyphenol-oxidase of soybean under field conditions

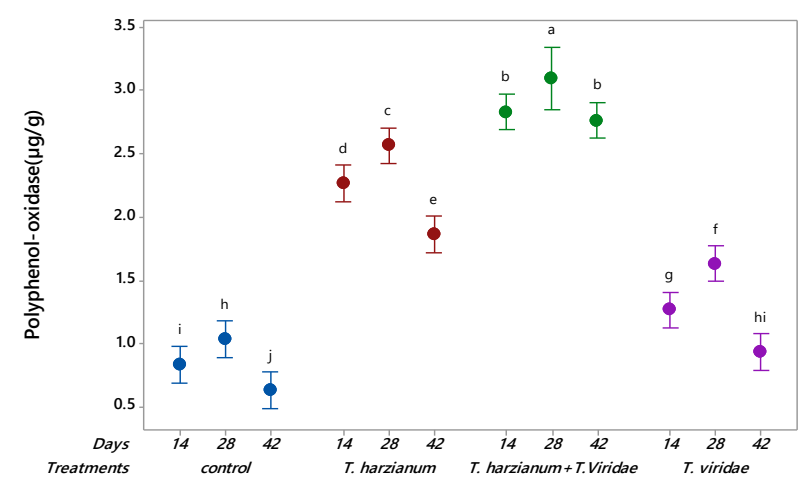

Individual standard deviations were used to calculate the intervals.

Fig. 12: Impact of interaction between fungal biocontrol agents and days on polyphenol-oxidase of soybean under field conditions

phenolics in soybean roots when seeds were sown after inoculation with $T$. harzianum isolates. Similarly, Rajeswari (2019) observed that leaves of Arachis hypogaea sprayed with combinations of $T$. viride and $T$. harzianum significantly increased phenols concentration. The study of Yusnawan et al. (2019) showed that the activity of

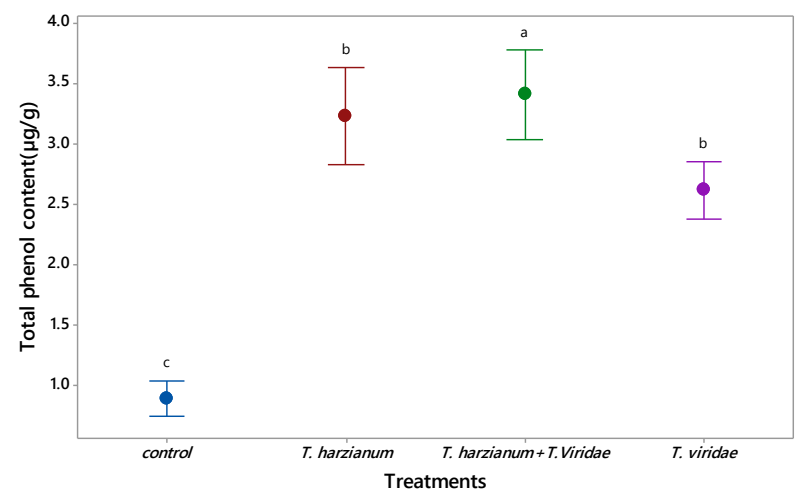

Individual standard deviations were used to calculate the intervals.

Fig. 13: Effect of fungal biocontrol agents on total phenol contents of soybean under greenhouse conditions

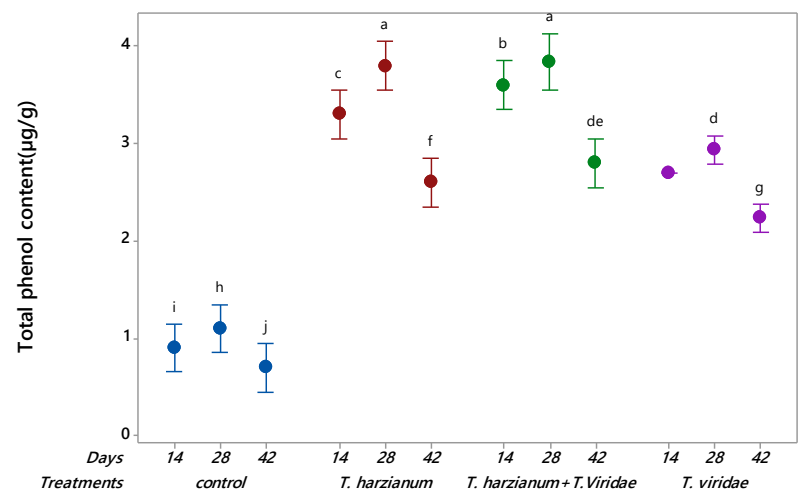

Individual standard deviations were used to calculate the intervals.

Fig. 14: Impact of interaction between fungal biocontrol agents and days on total phenol contents of soybean under greenhouse conditions

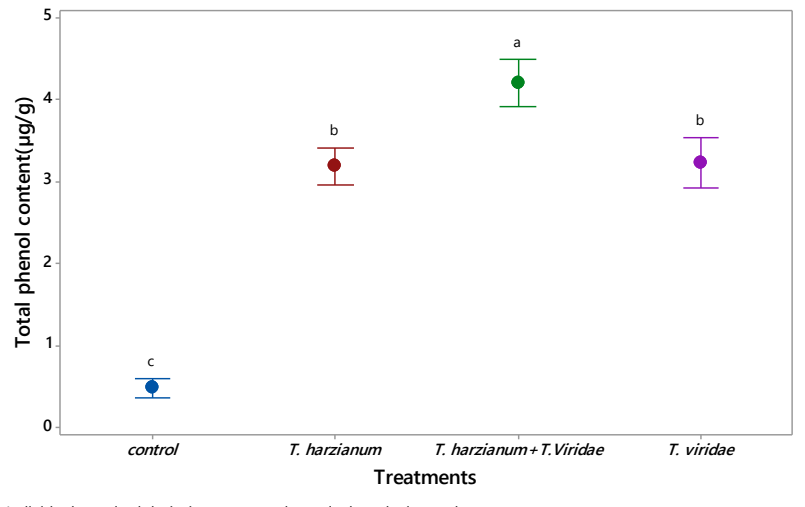

Fig. 15: Effect of fungal biocontrol agents on total phenol contents of soybean under field conditions

peroxidase increased in soybean plants treated with $T$. virens. Phenolics are one of the largest and most diverse groups of plant active substances involved in the plant growth regulation, and also play important role in defense 


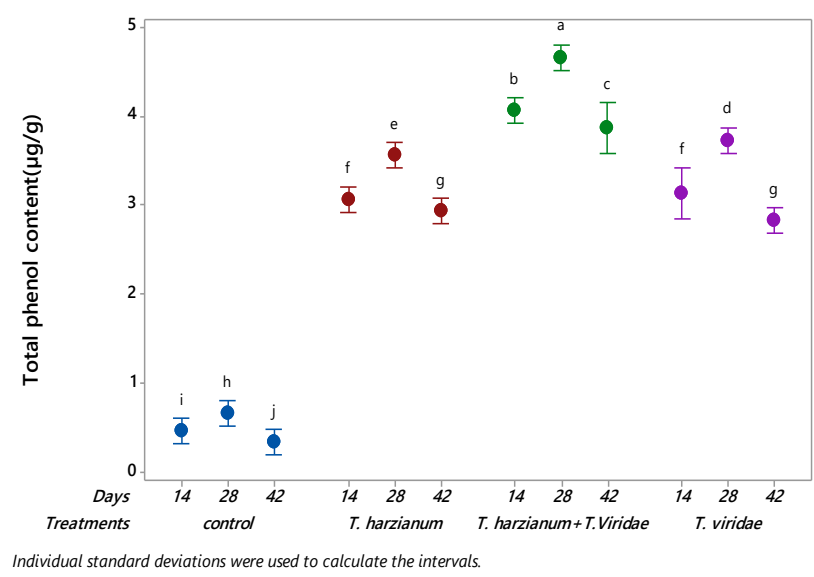

Fig. 16: Impact of interaction between fungal biocontrol agents and days on total phenol contents of soybean under field conditions

responses during pathogen infection and abiotic stress (Kubalt 2016). Phenolic compounds are produced by plant when the plant recognizes harmful pathogens or beneficial microbes. Polyphenol oxidase is involved in synthesis of phytoalexin and phenolic compounds, and the studies show that activity of polyphenol oxidase increases in legumes when treated with T. viride (Surekha et al. 2014). Seed treatment with $T$. virens increased the accumulation of total phenols in legumes (Inayati et al. 2020). PPO has been suggested to play important role in disease resistance due to its ability to catalyze oxidation of phenolic compounds into quinones and lignin biosynthesis (Kavitha and Umesha 2008; Inayati et al. 2020). According to the reported study, it is suggested that the induction of plant resistance in different hosts may require different signaling, and the induction is represented in different manner (MartínezMedina et al. 2014). An increase of phenolic contents was also observed in soybean when seeds were treated with $T$. virens (Yusnawan et al. 2019). Trichoderma species have been studied for decades as effective bio-control agents against many pathogens through various modes of action (Inayati et al. 2020) and these Trichoderma spp., can induce systemic resistance in various plant species and pathogens (Angel et al. 2016; Małolepsza et al. 2017). The study of Dubey et al. (2018) showed that there were upregulated expression of some defense-related genes and catalase in response to the presence of $T$. virens and $R$. solani. Numerous studies indicate the ability of Trichoderma spp. to reprogram plant genes expression that changes plant proteome and metabolome which alleviates physiological and biochemical change, and improve plant resistance to biotic and abiotic stresses (Mazzei et al. 2016). In plants, Trichoderma is able to activate plant defense mechanisms mostly for induced systemic resistance. Studies show that Trichoderma colonization triggers the plant defense systems (Pieterse et al. 2014; Inayati et al. 2020).

\section{Conclusion}

The present study showed that combining of T. harzianum with $T$. viride significantly increased the peroxidase, polyphenol oxidase, phenolics, polyphenol and $\beta-1,3-$ glucanase concentration in soybean compared to $T$. harzianum or $T$. viride alone. The increase in peroxidase, polyphenol oxidase, phenolics, polyphenol and $\beta-1,3$ glucanaseactivity and phenols concentration demonstrates that $T$. harzianum $+T$. viride are synergistic and have beneficial impact on growth of soybean plants.

\section{Acknowledgements}

Authors acknowledge the Dr. Usman Ghazanfer from department of Plant Pathology, College of Agriculture, University of Sargodha and Dr. Muhammad Atiq from Department of Plant Pathology, University of Agriculture, Faisalabad, for their support in data analysis.

\section{Author Contributions}

ZI and STS planned the experiments and AI interpreted the results and wrote the manuscript.

\section{Conflicts of Interest}

All authors declare no conflicts of interest.

\section{Data Availability}

Data presented in this study will be available on a fair request to the corresponding author.

\section{Ethics Approval}

Not applicable in this paper

\section{References}

Afouda LC, D Schulz, G Wolf, K Wydra (2012). Biological control of Macrophomina phaseolina on cowpea (Vigna unguiculata) under dry conditions by bacterial antagonists. Intl J Biol Chem Sci 6:50685077

Akhtar R, A Javaid (2018). Biological management of basal rot of onion by Trichoderma harzianum and Withania somnifera. Plant Danin 36; Article e 018170507

Ali A, A Javaid, A Shoaib, IH Khan (2020). Effect of soil amendment with Chenopodium album dry biomass and two Trichoderma species on growth of chickpea var. Noor 2009 in Sclerotiumrolfsii contaminated soil. Egypt J Biol Pest Cont 30; Article 102

Aly AA, A Mohamed, Abdel-Sattar, R Moawad, OA Kamel, Abd-Elsalam (2007). Differential antagonism of Trichoderma spp. against Macrophomina phaseolina. J Plant Prot Res 47:91-102

Angel LPL, MT Yusof, IS Ismail, BTY Ping, INAM Azni, NH Kamarudin, S Sundram (2016). An in vitro study of the antifungal activity of Trichoderma virens $7 \mathrm{~b}$ and a profile of its non-polar antifungal components released against Ganoderma boninense. J Microbiol $54: 732-744$ 
Anis M, W Abbasi, MJ Zaki (2010). Bioefficacy of microbial antagonists against Macrophomina phaseolina on sunflower. Pak J Bot 42:2935-2940

Banaras S, A Javaid, IH Khan (2021). Bioassays guided fractionation of Ageratum conyzoides extract for the identification of natural antifungal compounds against Macrophomina phaseolina. Intl $J$ Agric Biol 25:761-767

Bray HG, WV Thorpe (1954). Analysis of phenolic compounds of interest in metabolism. Meth Biochem Anal 1:27-52

Brotman Y, U Landau, A Cuadros-Inostroza, T Takayuki, AR Fernie, I Chet, A Viterbo, L Willmitzer (2013). Trichoderma-plant root colonization: Escaping early plant defense responses and activation of the antioxidant machinery for saline stress tolerance. PLoS Pathog 9; Article e1003221

Dubey SC, A Tripathi, R Tak (2018). Expression of defense-related genes in mung bean varieties in response to Trichoderma virens alone and in the presence of Rhizoctonia solani infection. 3Biotech 8; Article 432

El-Gamal NG, AN Shehata, ER Hamed, HS Shehata (2016). Improvement of lytic enzymes producing Pseudomonas fluorescens and Bacillus subtilis isolates for enhancing their biocontrol potential against root rot disease in tomato plants. Res J Pharm Biol Chem Sci 7:13931400

Etebarian H (2006). Evaluation of Trichoderma isolates for biological control of charcoal stem rot in melon caused by Macrophomina phaseolina. J Agric Sci Technol 8:243-250

Fehrmann H, AJP Dimond (1967). Peroxidase activity and Phytophthora resistance in different organs of potato plant. J Plant Pathol 57:69 77

Ganeshamoorthi P, T Anand, A Saravanan, V Prakasam, N Chandramohan, N Ragupathi (2010). Cultural and genetic variability in Macrophomina phaseolina (Tassi.) Goid. and incidence of mulberry root rot. Arch Phytopathol 20:123-132

Harman GE (2006). Overview of mechanisms and uses of Trichoderma spp. Phytopathology 96:190-194

Inayati A, L Sulistyowati, LQ Aini, E Yusnawan (2020). Trichoderma virens-Tv4 enhances growth promoter and plant defense-related enzymes of mungbean (Vigna radiata) against soil-borne pathogen Rhizcoctonia solani. Biodivers J Biol Divers 21:2410-2419

Javaid A, A Ali, A Shoaib, IH Khan (2021). Alleviating stress of Sclertium rolfsii on growth of chickpea var. Bhakkar-2011 by Trichoderma harzianum and T. viride. J Anim Plant Sci 31: in press

Javaid A, IH Khan, A Shoaib (2018). Management of charcoal rot of mungbean by two Trichoderma species and dry biomass of Coronopus didymus. Plant Daninha 36; Article e018182795

Javaid A, L Afzal, A Shoaib (2017). Biological control of charcoal rot of mungbean by Trichoderma harzianum and shoot dry biomass of Sisymbrium irio. Plant Danin 35; Article e017165756

Javed S, Z Mahmood, KM Khan, SD Sarker, A Javaid, IH Khan, A Shoaib (2021). Lupeol acetate as a potent antifungal compound against opportunistic human and phytopathogenic mold Macrophomina phaseolina. Sci Rep 11; Article 8417

Karthikeyan OP, S Nadarajan, PK Lee, K Heimann (2015). Effect of $\mathrm{CH}_{4} / \mathrm{O}_{2}$ ratio on fatty acid profile and polyhydroxy butyrate content in a heterotrophic-methanotrophic consortium. Chemosphere 141:235-242

Kavitha R, S Umesha (2008). Regulation of defense-related enzymes associated with bacterial spot resistance in tomato. Phytoparasitica 36:144-160

Khaledi N, P Taheri (2016). Biocontrol mechanisms of Trichoderma harzianum against soybean charcoal rot caused by Macrophomina phaseolina. J Plant Prot Res 56:21-31

Khan IH, A Javaid (2020a). Comparative antifungal potential of stem extracts of four quinoa varieties against Macrophomina phaseolina. Intl J Agric Biol 24:441-446

Khan IH, A Javaid (2020b). In vitro biocontrol potential of Trichoderma pseudokoningii against Macrophomina phaseolina. Intl J Agric Biol 24:730-736

Khan IH, A Javaid, D Ahmed (2021). Trichoderma viride controls Macrophomina phaseolina through its DNA disintegration and production of antifungal compounds. Intl J Agric Biol 25:888-894
Kubalt K (2016). The role of phenolic compounds in plant resistance. Biotechnol Food Sci 80:97-108

Kumar S (2013). Trichoderma: A biological control weapon for managing plant diseases and promoting sustainability. Intl J Agric Sci Vet Med $1: 106-121$

Mahadevan A, R Sridhar (1982). Methods of physiological plant pathology, $2^{\text {nd }}$ Edition. Sivakasi Publication, Madras, India

Mahdizadeh V, N Safaie, E Goltapeh (2011). Diversity of Macrophomina phaseolina based on morphological and genotypic characteristics in Iran. Plant Pathol J 27:128-137

Malmierca MG, RE Cardoza, NJ Alexander, SP McCormick, R Hermosa, E Monte, S Gutiérrez (2012). Involvement of Trichoderma trichothecenes in the biocontrol activity and induction of plant defense-related genes. Appl Environ Microbiol 78:4856-4868

Małolepsza U, J Nawrocka, M Szczech (2017). Trichoderma virens 106 inoculation stimulates defense enzyme activities and enhances phenolic levels in tomato plants leading to lowered Rhizoctonia solani infection. Biocontr Sci Technol 27:180-199

Marquez N, ML Giachero, S Declerck, DA Ducasse (2021). Macrophomina phaseolina: general characteristics of pathogenicity and methods of control. Front Plant Sci 12; Article 634397

Martínez-Medina A, MDM Alguacil, JA Pascual, SC Wees (2014). Phytohormone profiles induced by Trichoderma isolates correspond with their biocontrol and plant growth-promoting activity on melon plants. J Chem Ecol 40:804-815

Mazzei P, F Vinale, SL Woo, A Pascale, M Lorito, A Piccolo (2016). Metabolomics by H-HRMAS-NMR of tomato plants treated with two secondary metabolites isolated from Trichoderma. J Agric Food Chem 64:1021-1055

Mengistu A, JD Ray, JR Smith, RL Paris (2007). Charcoal rot disease assessment of soybean genotypes using a colony forming unit index. Crop Sci 47:2453-2461

Mukhopadhyay R, D Kumar (2020). Trichoderma: a beneficial antifungal agent and insights into its mechanism of biocontrol potential. Egypt $J$ Biol Pest Contr 30:1-8

Naher L, U Yusuf, A Ismail, K Hossain (2014). Trichoderma spp.: A biocontrol agent for sustainable management of plant diseases. Pak J Bot 46:1489-1493

Nishad R, T Ahmed, VJ Rahman, A Kareem (2020). Modulation of plant defense system in response to microbial interactions. Front Microbiol 11; Article 1298

Pieterse CMJ, C Zamioudis, RL Berendsen, DM Weller, SCMV Wees, PAHM Bakker (2014). Induced systemic resistance by beneficial microbes. Апnи Rev Phytopathol 52:347-375

Rajeswari P (2019). Combination of Trichoderma viride and Pseudomonas fluorescens for the enhanced control of Fusarium wilt disease caused by Fusarium oxysporum infecting Arachis hypogaea L. J Appl Nat Sci 11:138-143

Shahid S, MR Khan (2019). Evaluation of biocontrol agents for the management of root-rot of mung bean caused by Macrophomina phaseolina. Ind Phytopathol 72:89-98

Sharf W, A Javaid, A Shoaib, IH Khan (2021). Induction of resistance in chili against Sclerotium rolfsii by plant growth promoting rhizobacteria and Anagallis arvensis. Egypt J Biol Pest Cont 31; Article 16

Shoaib A, M Munir, A Javaid, AZ Awan, M Rafiq (2018). Anti-mycotic potential of Trichoderma spp. and leaf biomass of Azadirachta indica against the charcoal rot pathogen Macrophomina phaseolina (Tassi) Goid. in cowpea. Egypt J Biol Pest Cont 28; Article 26

Sreedevi B, MC Devi, DVR Saigopal (2011). Isolation and screening of effective Trichoderma spp. against the root rot pathogen Macrophomina phaseolina. J Agric Technol 7:623-635

Surekha C, N Neelapu, BS Prasad, PS Ganesh (2014). Induction of defense enzymes and phenolic content by Trichoderma viride in Vigna mungo infested with Fusarium oxysporum and Alternaria alternata. Intl J Agric Sci Res 4:31-40

Thilagavathi R, D Saravanakumar, N Ragupathi, R Samiyappan (2007). A combination of biocontrol agents improves the management of dry root rot (Macrophomina phaseolina) in green gram. Phytopathol Mediterr 46:157-167 
Ueki A, T Takehara, G Ishioka, N Kaku, K Ueki (2020). $\beta$-1, 3-Glucanase production as an anti-fungal enzyme by phylogenetically different strains of the genus Clostridium isolated from anoxic soil that underwent biological disinfestation. Appl Microbiol Biotechnol 104:5563-5578

Um-e-Aiman, N Nisar, T Tsuzuki, A Lowe, JT Rossiter, A Javaid, G Powell, R Waseem, SH Al-Mijalli, M Iqbal (2021). Chitin nanofibers trigger membrane bound defense signaling and induce elicitor activity in plants. Intl J Biol Macromol 178:253262
Wu S, L Shan, P He (2014). Microbial signature-triggered plant defense responses and early signaling mechanisms. Plant Sci 228:118-126

Yasmin H, R Naz, ANosheen, MN Hassan, N Ilyas, M Sajjad, Z Geng (2020). Identification of new biocontrol agent against charcoal rot disease caused by Macrophomina phaseolina in soybean (Glycine max). Sustainability 12; Article 6856

Yusnawan E, A Inayati, Y Baliadi (2019). Effect of soybean seed treatment with Trichoderma virens on its growth and total phenolic content. In: AIP Conference Proceedings, 2120, No. 1. AIP Publishing LLC, New York, USA 